\title{
MORPHOLOGICAL POLYMORPHISM IN AN URBAN POPULATION OF PTEROSTICHUS MELANARIUS (ILLIGER, 1798) (COLEOPTERA, CARABIDAE)
}

\author{
Viktor V. Brygadyrenko \& Olexij V. Korolev \\ Oles Honchar Dnipropetrovsk National University, pr. Gagarina, 72, Dnipropetrovsk, 49010, Ukraine \\ E-mail: alekseykorolev07@mail.ru; brigad@ua.fm
}

\begin{abstract}
We examined polymorphism in an urban population of the ground beetle Pterostichus melanarius (Illiger, 1798) in forest plantations on the outskirts of Dnipropetrovsk (Ukraine). We took measurements for 130 males and 95 females according to 14 metric, 10 non-metric parameters and 10 indices. According to 13 out of the 14 metric parameters (except for the length of the flight wings) P. melanarius showed a significant sexual dimorphism. The female specimens showed a normal distribution in body length and the males showed a significant positive excess. The 10 most significant body proportions of the ground beetles showed much lower sexual differences $(0.26 \pm 0.86 \%)$ compared to linear measurements $(6.56 \pm 0.96 \%)$. Females and males are practically isomorphic: when one metric parameter decreases, another decreases proportionally. Statistically significant differences between males and females were registered only for the ratio of elytra to length of prothorax, width of elytra to maximum width of prothorax and length of elytra to their width. A highly significant excess was registered in 6 out of 10 assessments of body proportions for females and 5 out of 10 for males. The coefficient of variation is minimal for body proportions and is maximal for metric parameters, which proves the existence of isomorphic differences between $P$. melanarius males and females. Out of 10 non-metric parameters a statistically significant sexual dimorphism $(P=0.01)$ was registered only for the shape of the front edge of the labrum (males mostly have a slightly concave, and females a strongly concave front edge of the labrum). Using PCA analysis it was established that $45.2 \%$ of the morphological variability of the studied population depends upon the individuals' sex: the whole complex of metric parameters (length and width of head, prothorax, elytra and parts of head, body height) taken together synchronically varies among individuals of different sex. More or less defined groups (morphotypes) were not found among the studied population of $P$. melanarius. The normal distribution of individuals in the studied population for a range of characteristics was altered by the impact of significant asymmetry or excess in certain features or ratios of metric characteristics. The data obtained can form the basis for monitoring the condition of $P$. melanarius populations, the individuals of which accumulate a large amount of toxins in conditions of anthropogenic impact.
\end{abstract}

Key words: variability in populations; body size; sexual dimorphism; Pterostichus melanarius; ground beetle.

\section{RESUMEN}

Polimorfismo morfológico de una población urbana de Pterostichus melanarius (Illiger, 1798) (Coleoptera, Carabidae)

Se ha examinado el polimorfismo de una población urbana del carábido Pterostichus melanarius (Illiger, 1798) en plantaciones forestales de las inmediaciones de Dnipropetrovsk (Ucrania). Se han estudiado 130 machos y 95 hembras mediante 14 parámetros métricos, 10 no métricos y 10 índices corporales. De acuerdo con 13 de los 14 parámetros métricos (a excepción de la longitud de las alas membranosas), P. melanarius mostró un dimorfismo sexual significativo. Las hembras mostraron una distribución normal en la longitud del cuerpo y los machos una diferencia significativa. Las 10 proporciones corporales más significativas de esta especie mostraron diferencias sexuales mucho menores $(0,26 \pm 0,86 \%)$ que las mediciones lineales $(6,56 \pm 0,96 \%)$. Las hembras y los machos tienen prácticamente la misma forma: cuando un parámetro indicador disminuye, otro lo hace también proporcionalmente. Se registraron diferencias estadísticamente significativas entre machos y hembras solo para las siguientes razones: longitud de los élitros/longitud del protórax, anchura de los élitros/anchura máxima del protórax y longitud/anchura de los élitros. Una diferencia muy significativa se registró en 6 de cada 10 cálculos de las proporciones corporales para las hembras y 5 de cada 10 para los machos. El coeficiente de variación es mínimo para las proporciones corporales y máximo para los parámetros métricos, lo que demuestra la existencia de diferencias de forma entre machos y hembras de P. melanarius. De los 10 parámetros no 


\begin{abstract}
métricos, se registró dimorfismo sexual estadísticamente significativo $(P=0,01)$ solo en la forma del borde delantero del labro (los machos en su mayoría tienen una ligera concavidad mientras que las hembras muestran dicho borde muy cóncavo). El Análisis de Componentes Principales (PCA) estableció que el 45,2\% de la variabilidad morfológica de la población estudiada depende del sexo de los individuos: los parámetros métricos (longitud y anchura de la cabeza, protórax, élitros y partes de la cabeza, altura corporal) varían en conjunto sincrónicamente entre los ejemplares de distinto sexo. No se encontraron grupos más o menos definidos (morfotipos) en la población estudiada de $P$. melanarius. La distribución normal de ciertos caracteres en los ejemplares de la población estudiada se vio modificada por una asimetría significativa o un exceso en ciertas características morfológicas o proporciones métricas. Los datos obtenidos pueden servir de base para el seguimiento del estado de las poblaciones de $P$. melanarius ya que los individuos acumulan una gran cantidad de toxinas en condiciones de impacto antropogénico.
\end{abstract}

Palabras clave: variabilidad poblaciones; tamaño corporal; dimorfismo sexual; Pterostichus melanarius; Carabidae.

Recibido/Received: 23/11/2014; Aceptado/Accepted: 15/04/2015; Publicado en línea/Published online: 05/06/2015

Cómo citar este artículo/Citation: Brygadyrenko, V. K. \& Korolev, O. V. 2015. Morphological polymorphism in an urban population of Pterostichus melanarius (Illiger, 1798) (Coleoptera, Carabidae). Grael/sia, 71(1): e025. http://dx.doi.org/10.3989/ graellsia.2015.v71.126

Copyright: (C) 2015 SAM y CSIC. Salvo indicación contraria, todos los contenidos de la edición electrónica de Grael/sia se distribuyen bajo licencia de uso y distribución Creative Commons Reconocimiento no Comercial 3.0. España (cc-by-nc).

\section{Introduction}

The study of morphological variability of invertebrate populations allows to evaluate the resistance of a population system, its capacity to retain constancy in dynamic environmental conditions, and the possibility of change within a species, deviation of individuals from average sizes (Sota et al., 2000; Brygadyrenko $\&$ Reshetniak, 2014). Those species of invertebrate animals which have a wide range in different continental climatic zones face a great variety of moisture and temperature conditions, which indirectly affects their trophic resources, causative agents of parasitic and contagious diseases. This finally leads to certain morphological types obtaining advantages within a population. Pathological morphological changes of insect imagines with complete metamorphosis occur under the influence of larval parasites, bacterial, viral and fungal pathogens. They can be evaluated using an index of asymmetry, the values of which reflects the intensity of somatic mutations when a whole complex of environmental factors influence an invertebrate's organism (Brygadyrenko \& Slynko, 2015). The absence of disfiguring mutations and of sharp deviations in the body structure of certain individuals in a population need not be an unambiguous indication that such a population is in a normal condition (Daly et al., 1998).

Morphometric study of variability of populations of ground beetles involves the expenditure of a significant amount of time in collecting the beetles, measuring them and analyzing the results, which may explain why very little work has been done in this sphere. While it would be of interest to study the variability of populations of rare species of ground beetle and those species that require protection, it would be equally rewarding to study the characteristics of common species of this family, which have a wide range and high degree of ecological flexibility (Brygadyrenko \& Fedorchenko, 2008; Brygadyrenko \& Slynko, 2015). One of the most abundant species in the ecosystems of almost the entire territory of Europe is Pterostichus melanarius (Illiger, 1798) (Thiele, 1977; Sharova, 1981; Den Boer, 1985; Kryzhanovskij et al., 1995; Hurka, 1996; Irmler, 2003).

The development cycle of $P$. melanarius can vary in different types of ecosystems: within populations the duration of certain stages of ontogenesis can change, as can the seasonal linkages of these stages (Hurka, 1975; Matalin, 2007). Under certain conditions this species undergoes two-year summer-autumn recycles, in other microclimatic conditions a one year variant of the cycle with overwintering of older larvae, and in others a two year cycle variant with overwintering imagines (Jørum, 1980; Basedov, 1994; Matalin, 2006, 2007). The high abundance of this species and its significance in destroying agricultural pests is acknowledged in many studies in field and laboratory conditions (Desender et al., 1985; Wallin, 1988; Wallin \& Ekbom, 1994; Frampton et al., 1995; Fadl et al., 1996; Symondson, 1997; Thomas et al., 1998; Chapman et al., 1999; Raworth \& Choi, 2001; Collins et al., 2002; Fournier \& Loreau, 2002; Raworth et al., 2004; Kitaev et al., 2011). The morphological variability of populations of this ground beetle species has until now remained poorly studied. The major focus of research attention has been the wing polymorphism of this species (Lovei, 1996; Matalin, 2003). Lovei (1996) points out that the percentage of P. melanarius individuals with fully functional wings is $2 \%$ lower in stable ecosystems (that are not affected by periodic flooding with water, for example in forests), 
and increases in conditions of unstable hydrologic regimes (for example in the polder ecosystems of the Netherlands, small river and lake islands of Poland).

The feeding of this species in laboratory conditions is decidedly nonselective. Until now it has been considered that $P$. melanarius consumes practically all species of invertebrate animals, even those over twice their weight (Thiele, 1977; Pollet \& Desender, 1985; Currie \& Digweed, 1996; Thomas et al., 2008). Invertebrates that contain in their body poorly studied poisonous compounds form an exception to this dietary pattern (Symondson, 1997). A detailed study of the diet of P. melanarius diet in laboratory conditions (Brygadyrenko \& Korolev, 2006; Korolev \& Brygadyrenko, 2012a, 2012b) allowed us to show that this species has an extremely wide range of diet compared to other species of the Pterostichus genus. Searching for an explanation for such a wide trophic range, we attempted to define the individual preferences of certain individuals (Korolev \& Brygadyrenko, 2014). Thus individual trophic preferences were identified for the first time for the ground beetle family. It was shown that trophic preferences did not correlate with any morphologic indicator (Korolev \& Brygadyrenko, 2014). For further analysis of the reasons for individual variability of trophic preferences, evaluation of the morphological variability of $P$. melanarius populations will be necessary. If a clearly defined morphotype in P. melanarius populations is found, further research into differences in their trophic preferences can be conducted.

Therefore we have set the following objectives for this research: (1) to define the general variability of morphometric characteristics in a P. melanarius population, (2) to find characteristics according to which sexual dimorphism will be most acutely manifested and (3) to define factors that contribute the most to morphometric variability of the studied population of P. melanarius.

\section{Material and methods}

The specimens were collected in June and July 2013 from a $P$. melanarius population in an artificial forest plantation in the area surrounding Zapadniy, Dnipropetrovsk, Ukraine $\left(48^{\circ} 27^{\prime} \mathrm{N}, 34^{\circ} 56^{\prime} \mathrm{E}\right)$. The beetles were collected using pit fall traps and manually from under logs, stones, plant remains. The studied forest plantation (Robinia pseudoacacia L., Quercus robur L., Ulmus laevis Pall., Acer negundo L.) is subjected to intensive anthropogenic impact: recreational pressure (accumulation of garbage, bonfires, damage from trampling), aerogenic pollution with industrial pollutants (heavy metals, formaline, phenol, sulfur and nitrogen oxides) as a result of the operation of the biggest industrial plants in the region (Pakhomov \& Brygadyrenko, 2005).

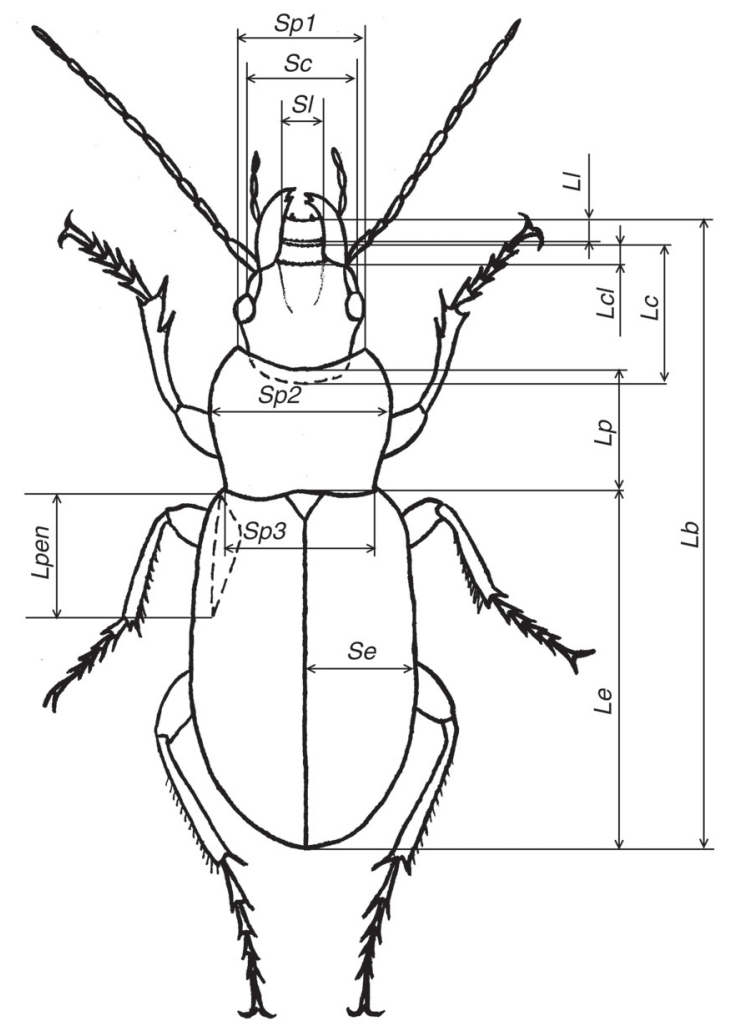

Fig. 1.- Scheme of morphological measurements of $P$. melanarius: see Notes to Table 1.

Fig. 1.- Medidas morfológicas de P. melanarius: véanse las Notas de la Tabla 1.

The collected ground beetles (130 males and 95 females) were put for a day in a freezing chamber and then dried out on paper-cotton wool sheets. The collected specimens were assessed according to 14 metric (Fig. 1) and 10 non-metric characteristics (Table 1). These characteristics are labeled as followed and this forms the key to Table 1 (all body measurements are in millimeters): $\mathrm{Lb}$ - length of body, from front edge of clypeus to elytra tips, Ll - length of labrum, S1 - width of labrum, Lcl - length of clypeus, Lc - length of head from front edge of clypeus to cervical suture, $\mathrm{Sc}$ - width of head before eyes, Lp - length of prothorax along the central line, Spl - width of prothorax front edge, $\mathrm{Sp} 2$ - maximum width of prothorax, Sp3 - width of prothorax back edge, $\mathrm{Hm}$ - maximum height (thickness) of body at the level of central part of metathorax, Le - length of elytra, $\mathrm{Se}$ - maximum width of elytra, Lpen - length of flight wings.

The following indices were calculated: $\mathrm{Lb} / \mathrm{Hb}$ - ratio of body length to body height, $(\mathrm{Sc}+\mathrm{Sp}+\mathrm{Se}) / 3 \mathrm{Lb}$ - ratio of average width of head, prothorax and elytra to body length, $\mathrm{Lp} / \mathrm{Sp} 2$ - ratio of prothorax length to its maximum width, Le/Lp - ratio of elytra length to prothorax length, Se/Sp2 - ratio of elytra width to maximum prothorax width, $\mathrm{Sp} 2 / \mathrm{Sp} 3$ - ratio of maximum prothorax width to width of its back edge, 


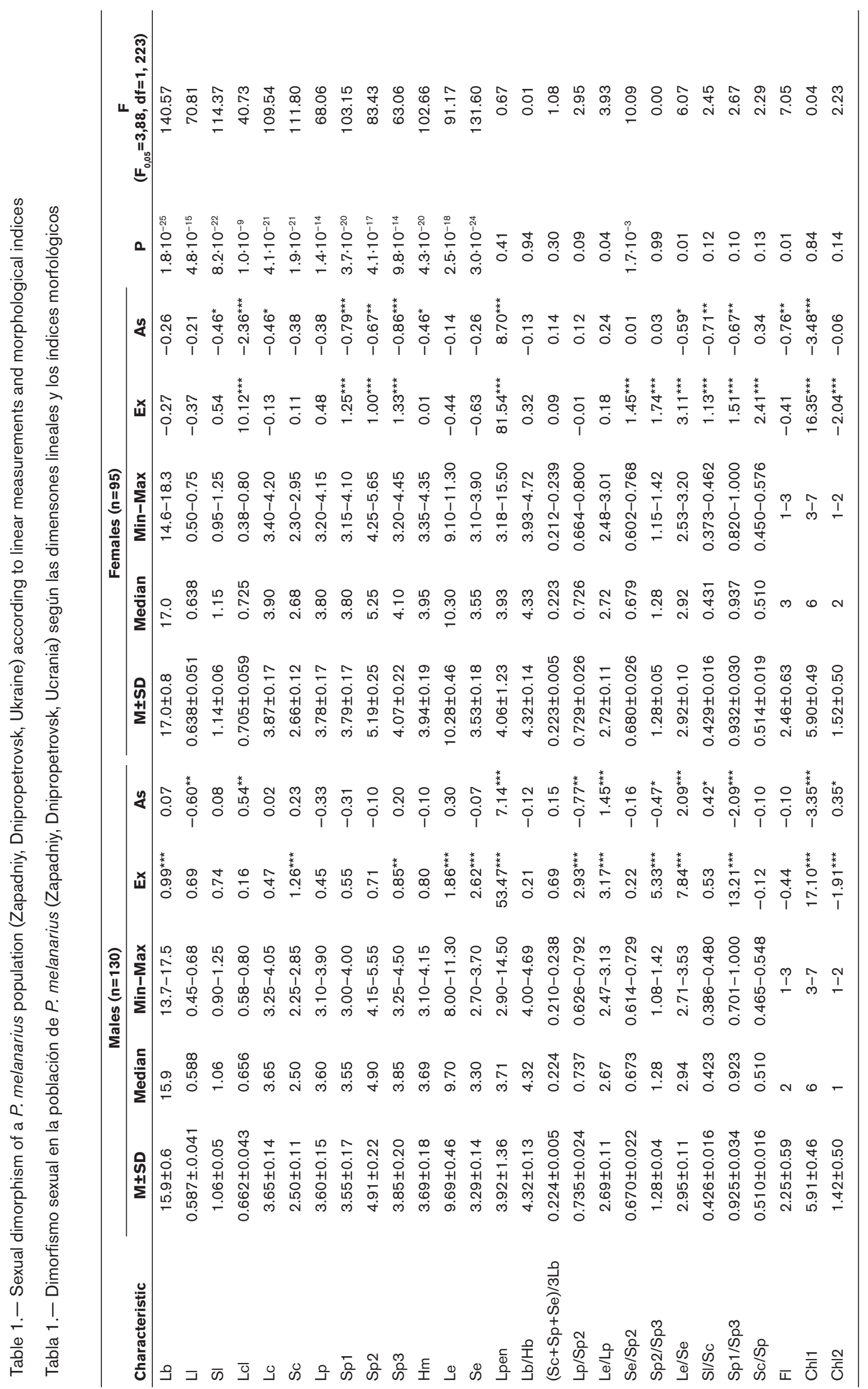




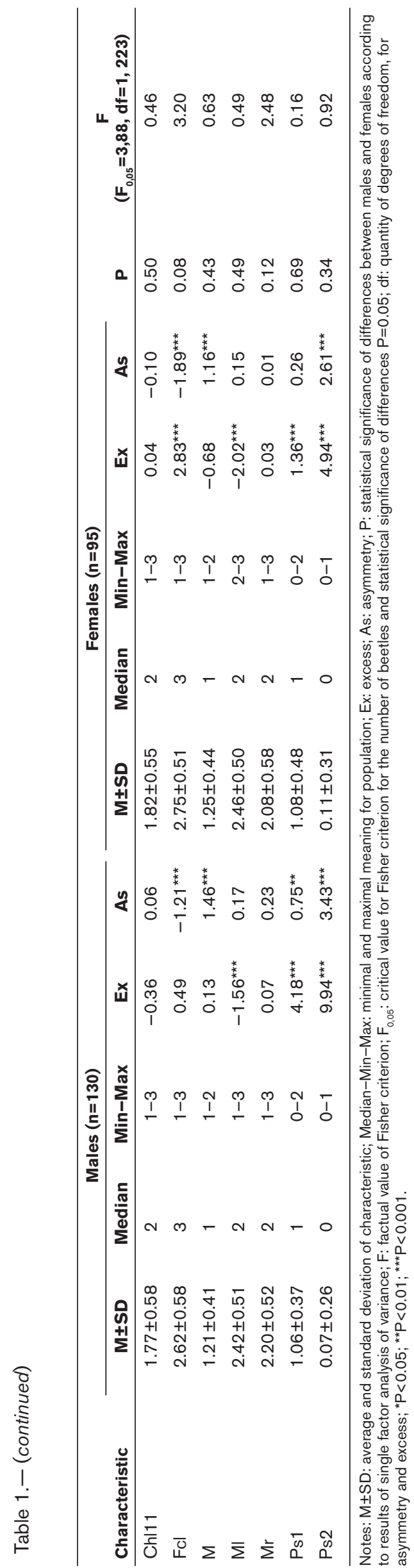

$\mathrm{Le} / \mathrm{Se}$ - ratio of elytra length to their width, $\mathrm{Sl} / \mathrm{Sc}-$ ratio of labrum width to head width, $\mathrm{Spl} / \mathrm{Sp} 3$ - ratio of prothorax width on front and back edges, $\mathrm{Sc} / \mathrm{Sp}$ - ratio head width to prothorax width.

The following non-metrical characteristics were analysed: F1 - shape of labrum front edge (1: straight, 2 : slightly concave, 3 : strongly concave), Chl1 - number of setae-bearing pores on labrum, Chl 2 - extent of indumentation of labrum front angles (1: weak indumentation, 2: strong indumentation), Ch111 - depth of setae-bearing pores on labrum (1: the surface is flat, 2: pores of average depth, 3 : setae-bearing pores are very deepened), $\mathrm{Fcl}$ - shape of clypeus front edge (1; concave, 2: straight, 3: convex), M - arrangement of mandibles (1: left mandible is on top of the right, 2: right mandible is on top of the left), $\mathrm{Ml}$ and $\mathrm{Mr}$ - depth of furrow on left and right mandibles respectively (1: slightly manifested furrows, 2: furrows of average depth, 3: deepened furrows), Psl - presence of transverse grooves on prothorax front edge (0: transverse grooves are absent, 1: one and 2: two curved transverse grooves), Ps2 - presence of indentations on front edge of prothorax ( 0 : absent, 1 ; indentations present). For the assessment of the most important body proportions 10 morphometric indices suggested by Sharova (1981) were used, and in addition ratios suggested by ourselves (Table 1).

The measurements of the beetles were taken using an eyepiece micrometer MBC-10 with accuracy to $0.05 \mathrm{~mm}$. When analyzing the characteristics average and standard deviation, minimal and maximal meanings, asymmetry and excess were determined. For determining the statistical significance of differences in averages single factor dispersion analysis was used. For finding factors that identify the variability of the morphological characteristics of $P$. melanarius we used PCA analysis (Statistica 8.0 program).

\section{Results and discussion}

For 13 out of 14 metric characteristics (except the length of flight wings) of $P$. melanarius there is a strongly significant $\left(\mathrm{P}=1 \cdot 10^{-9}\right.$ and lower) sexual dimorphism (Table 1). Females are larger than males, the greatest difference (Figs. 2-4) is for the labrum (the value for females is on average $8.8 \%$ higher than for males), maximum width of elytra $(7.4 \%)$, width of labrum $(7.3 \%)$, length of body $(6.8 \%)$, maximum body height (6.8), width of front edge of prothorax $(6.6 \%)$, length of clypeus $(6.5 \%)$, width of head $(6.5 \%)$, length of elytra (6.1\%), length of head $(5.9 \%)$, maximum width of prothorax $(5.8 \%)$, width of back edge of prothorax (5.8\%), length of prothorax $(4.9 \%)$, length of flight wings $(3.7 \%)$. If we take out of consideration the length of the flight wings, then on average for 13 metric characteristics of $P$. melanarius the size of females is $6.56 \pm 0.96 \%$ greater than those of males. 

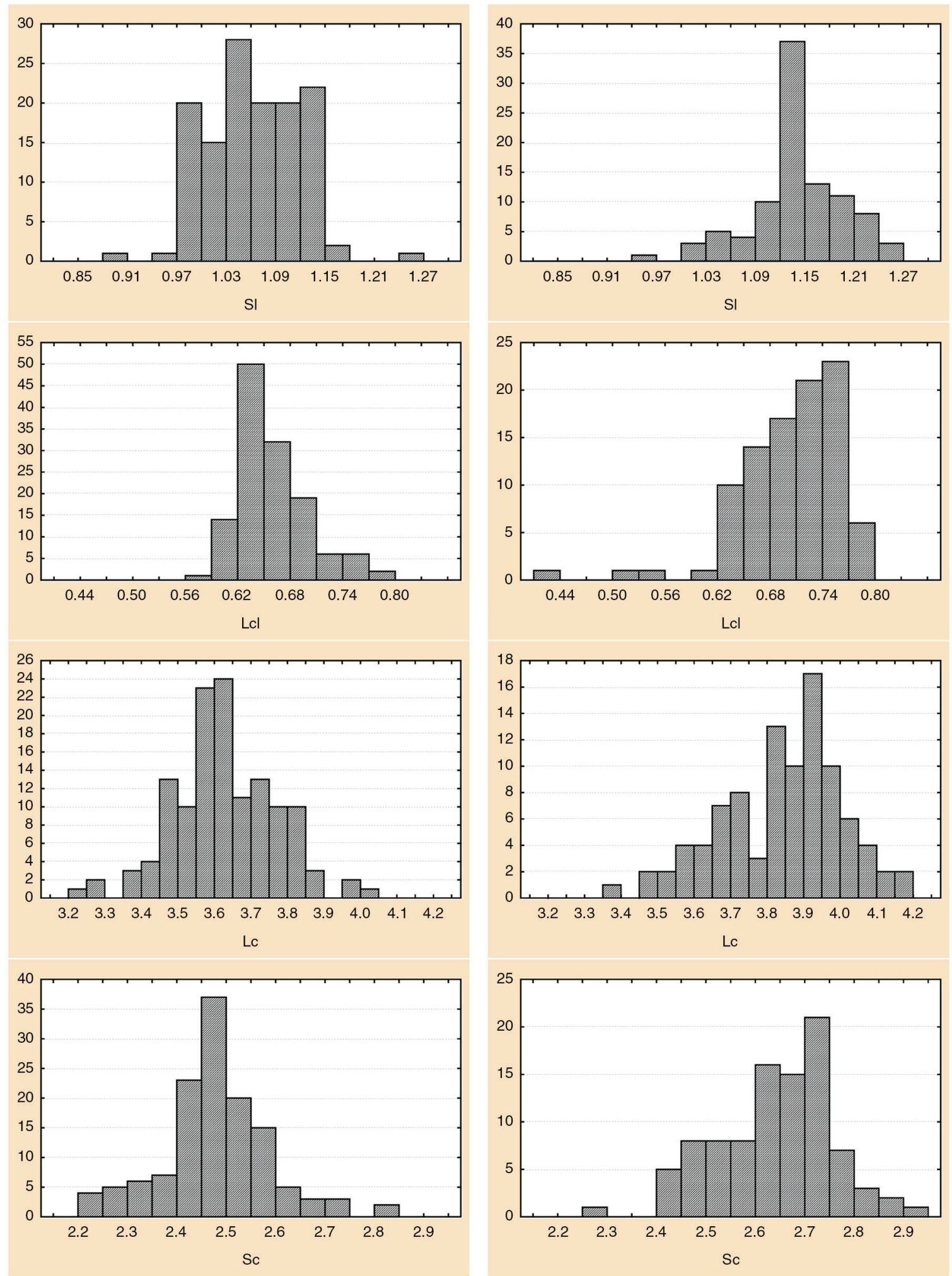

Fig. 2.- Variability of upper labrum width (SI), length of clypeus (Lcl), length (Lc) and width of head (Sc) of $P$. melanarius. On the left males $(n=130)$, on the right females $(n=95)$; abscissa axis, values of characteristics $(\mathrm{mm})$; ordinate axis, number of specimens.

Fig. 2. - Variabilidad de la anchura del labro superior (SI), longitud del clípeo (Lcl) y longitud (Lc) y anchura de la cabeza (Sc) de P. melanarius. A la izquierda, machos $(n=130)$ y a la derecha, hembras $(n=95)$; abscisas, dimensiones $(m m)$; ordenadas, número de ejemplares.

Apart from average values the range of variability of the studied metric characteristics also varies (Figs. 2-4): females have a $88.9 \%$ greater length of clypeus, $18.8 \%$ greater length of prothorax, $11.1 \%$ length of labrum and $8.3 \%$ greater length of head. At the same time, males have a $33.3 \%$ greater variability 


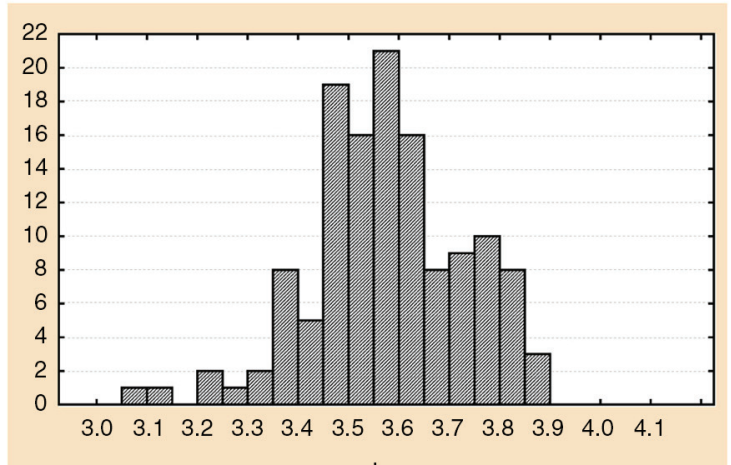

Lp

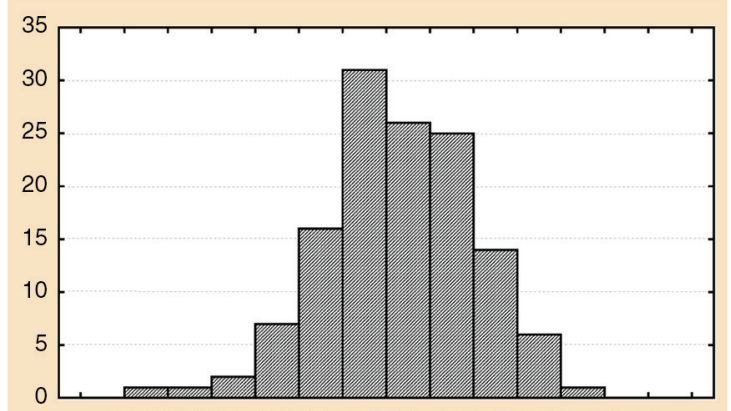

2.93 .03 .13 .23 .33 .43 .53 .63 .73 .83 .94 .04 .1

Sp1
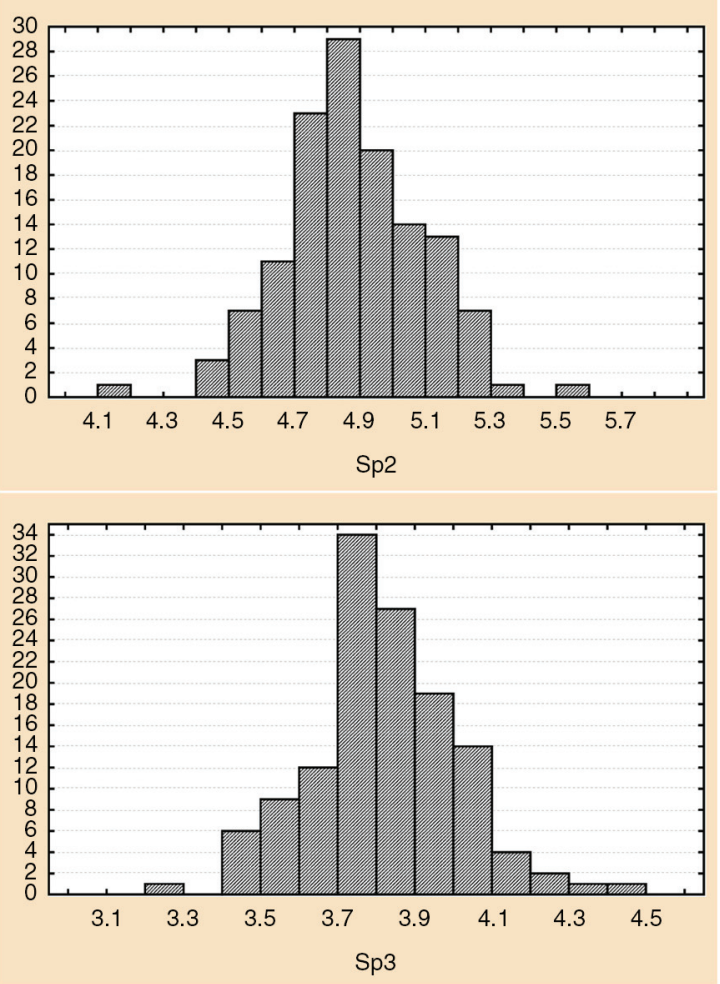

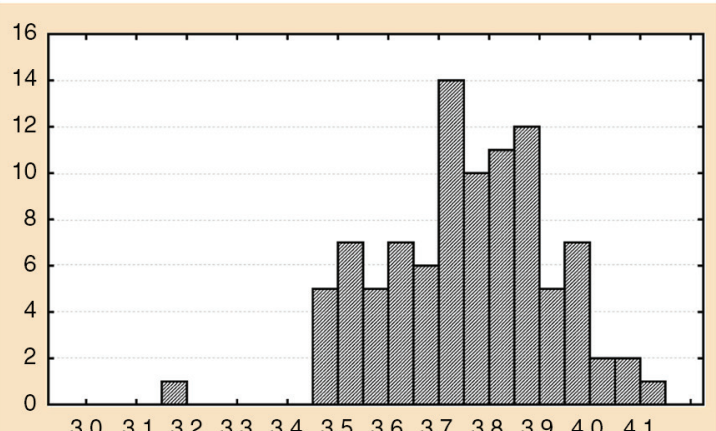

Lp

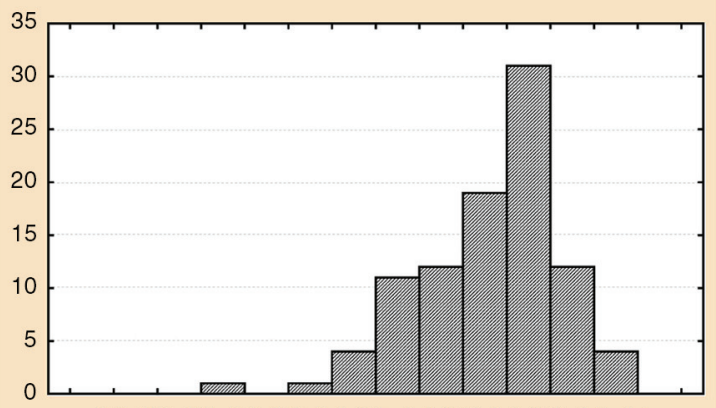

2.93 .03 .13 .23 .33 .43 .53 .63 .73 .83 .94 .04 .1

$\mathrm{Sp} 1$
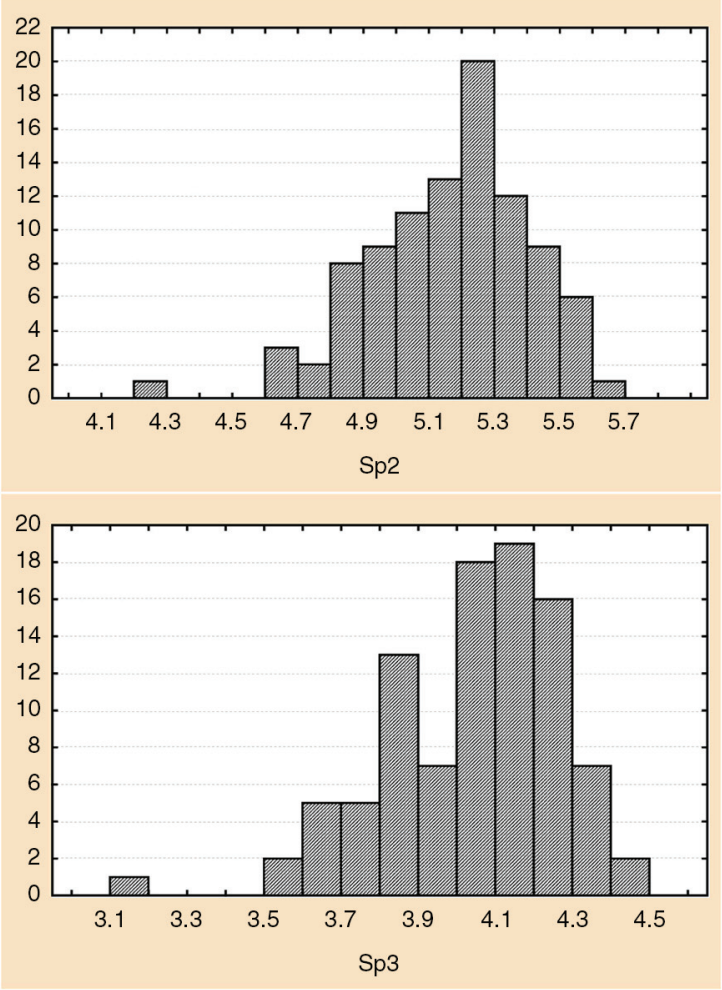

Fig. 3. - Variability of length of prothorax (Lp), maximum width of prothorax (Sp2), width of prothorax at front (Sp1) and back edges (Sp3) of $P$. melanarius. On the left males $(n=130)$, on the right females $(n=95)$; abscissa axis, values of characteristics $(\mathrm{mm})$; ordinate axis, number of specimens.

Fig. 3.- Variabilidad de la longitud del protórax (Lp), la anchura máxima del protórax (Sp2) y la anchura del protórax en el borde anterior (Sp1) y posterior (Sp3) de P. melanarius. A la izquierda, machos $(n=130)$ y a la derecha, hembras $(n=95)$; abscisas, dimensiones $(\mathrm{mm})$; ordenadas, número de ejemplares.

of length of elytra, $200 \%$ width of elytra, $14,3 \%$ width of labrum, $2.6 \%$ length of body, $5.0 \%$ width of front edge of prothorax, $4.8 \%$ body height.
For body length a normal distribution of individuals in the population was observed for females (excess and asymmetry are statistically insignificant, Table 1) 


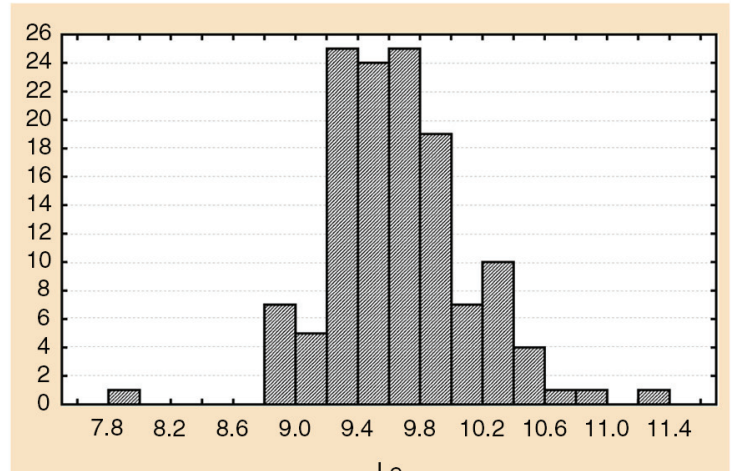

Le

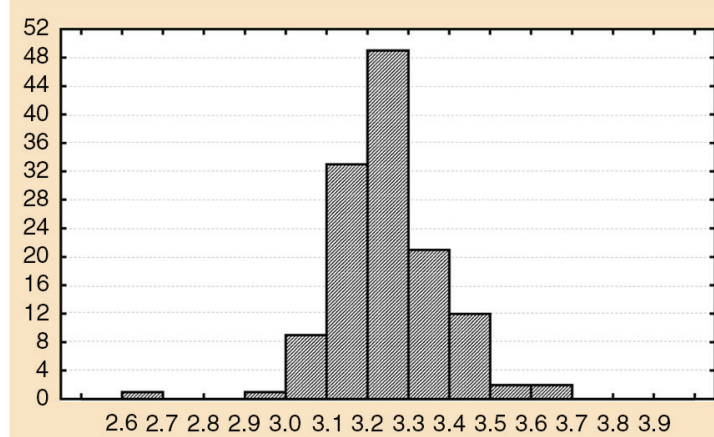

$\mathrm{Se}$

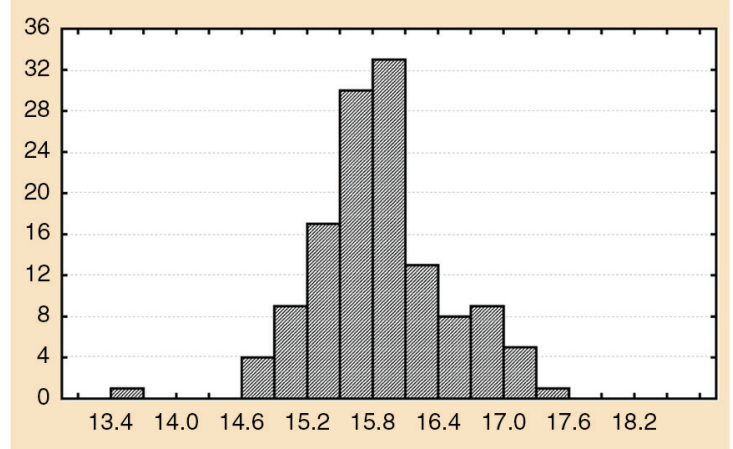

Lb

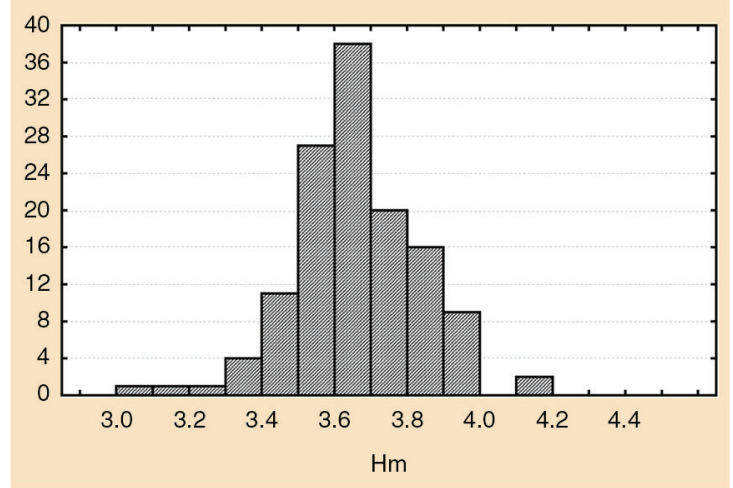

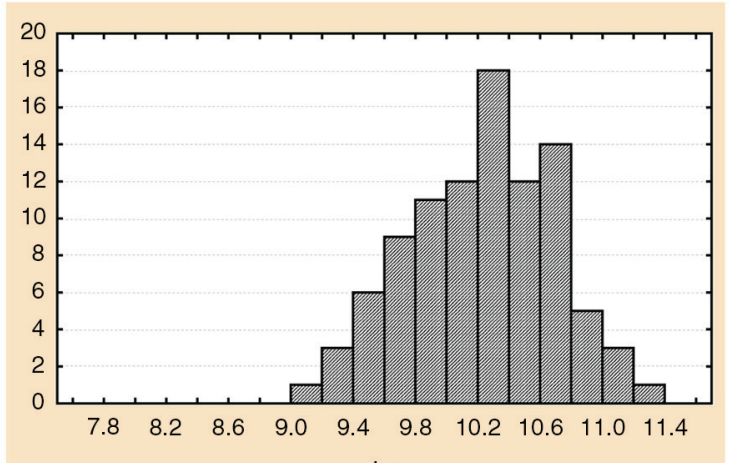

Le

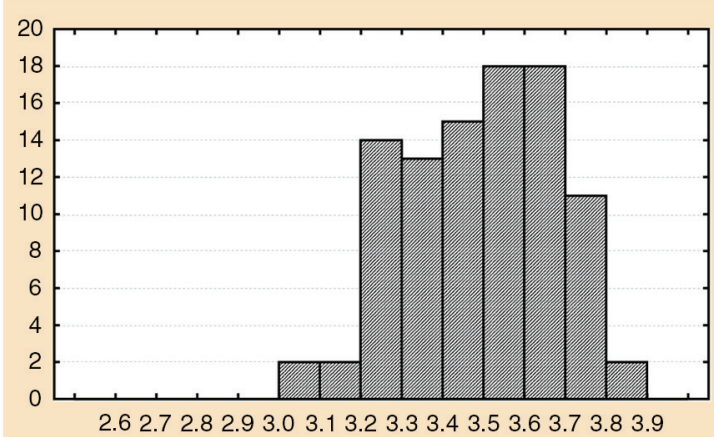

$\mathrm{Se}$

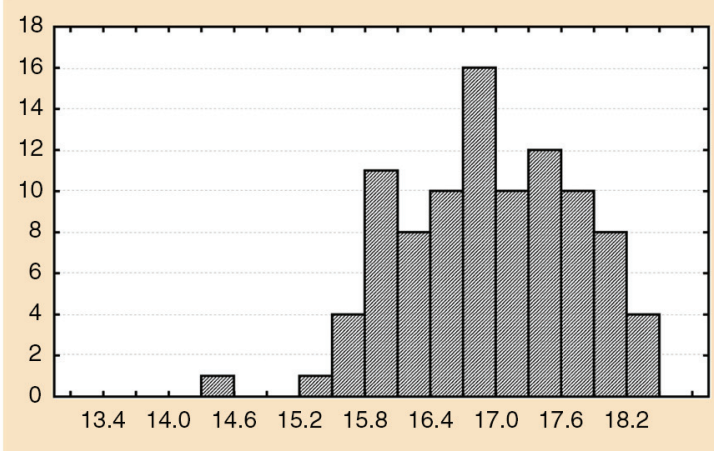

Lb

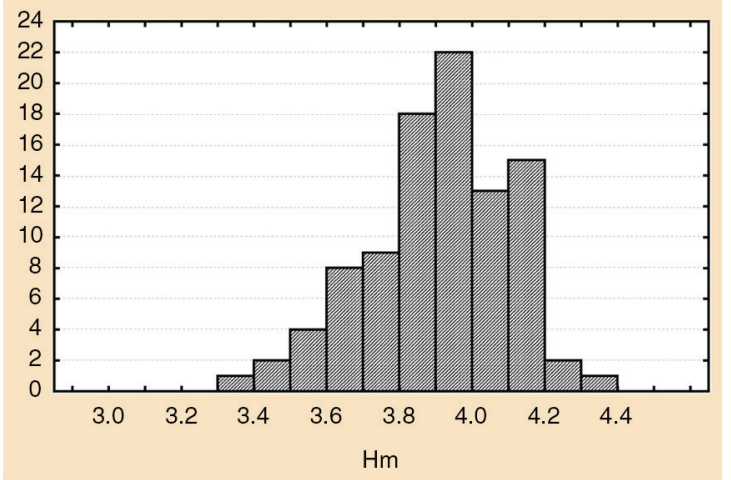

Fig. 4. - Variability of length (Le) and maximum width of elytra (Se), length ( $\mathrm{Lb})$ and height of body (Hm) of $P$. melanarius. On the left males $(n=130)$, on the right females $(n=95)$; abscissa axis, values of characteristics $(\mathrm{mm})$; ordinate axis, number of specimens.

Fig. 4.- Variabilidad de la longitud (Le) y la anchura máxima de los élitros (Se) y la longitud (Lb) y la anchura del cuerpo (Hm) de P. melanarius. A la izquierda, machos $(n=130)$ y a la derecha, hembras $(n=95) ;$ abscisas, dimensiones $(m m)$; ordenadas, número de ejemplares.

Males, on the contrary, showed a statistically significant $(\mathrm{P}<0.001)$ positive excess. According to Geodakyan (1983), the smaller size of males compared to females (in this case by $6.8 \%$ ) indicates a gradual decrease in body sizes of the species in the process of evolution. However, in the case of $P$. melanarius this decrease has 
stabilised, which indicates an absence of asymmetry in distribution of the body length of the males collected for study. A similar distribution is seen in the head width of $P$. melanarius: females have a normal distribution, males have a statistically significant $(\mathrm{P}<0.001)$ positive excess (a sharply peaked distribution is observed).

The length of prothorax of males and females shows a normal distribution (Table 1, Fig. 3), and within this distribution were observed the least significant sexual differences out of the 13 metric characteristics (only $4.9 \%$ ), which indicate the microevolutionary stability of this characteristic.

For width of front and back edges, and also maximum width, of the females' prothorax (Table 1, Fig. 3) a statistically significant positive excess was registered $(\mathrm{P}<0.001$, i.e. distribution of the characteristic "peaked") and a negative asymmetry $(\mathrm{P}<0.01$, i.e. individuals dominate with greater values of measurements, compared to average). Males have no statistically significant asymmetry according to the three measurements of prothorax width.

Body height is, on one hand, connected with the ability to shelter in narrow crevices under stones, in cracks in the soil etc., and on the other hand with the ability of females to increase reproductive capacity (increase in belly volume not only due to length and width of elytra, but also due to body height). The distribution of $P$. melanarius males according to body height is normal (i.e. body height is optimal for living in the shelter of litter and soil horizons), among females there was observed a negative asymmetry $(\mathrm{P}<0.01)$, connected with presence (among the females collected) of a small amount of individuals that oviposited at the time of collecting beetles (June, July).

It is interesting to note that a normal distribution of individuals was registered in the studied $P$. melanarius population according to length and width of elytra of females and a sharply peaked distribution (positive excess, $\mathrm{P}<0.001$ ) for these characteristics among males (Table 1, Fig. 4). The absence of statistically significant asymmetry for length and width of elytra among individuals of both sexes either sex indicates the stability of these parameters.

Length of the flight wings for $P$. melanarius is characterized by acute polymorphism (Table 1), which reaches $14.3-15.5 \mathrm{~mm}$ in long-winged individuals in the population we studied ( 1 of 95 females and 2 of 130 males). Among short-winged males $(3.75 \pm 0.37 \mathrm{~mm})$ and females $(3.94 \pm 0.33 \mathrm{~mm})$ the length of wings differed significantly between the sexes $\left(\mathrm{F}=15.17, \mathrm{~F}_{005}=3.88, \mathrm{P}=1.3 \cdot 10^{-4}\right)$. On average, according to the number of long-winged individuals $(1.3 \%)$, the studied population can be characterized as a stable lowland $P$. melanarius population, in which long-winged individuals do not obtain advantage (Lovei, 1996; Matalin, 2003).

For determining the most significant body proportions of the ground beetles we examined 10 indices, which in general showed a much lower sexual dimorphism $(0.26 \pm 0.86 \%)$ compared to linear measurements $(6.56 \pm 0.96 \%)$. In other words, females and males are according to 10 the examined indices, practically isomorphic (with decrease in one of the metric characteristics, another one also decreases, and on the contrary with an increase in one, there is an increase in another). Statistically significant differences (Table 1, Figs. 5-6) between males and females were registered only for ratio of length of elytra to prothorax length (Le/Lp, $\mathrm{P}=0.04$, among females this on average is $1.1 \%$ higher), width of elytra to maximum width of prothorax $(\mathrm{Se} / \mathrm{Sp} 2, \mathrm{P}=0.0013$, among females is $1.5 \%$ higher compared to males) and length of elytra to their width ( $\mathrm{Le} / \mathrm{Se}, \mathrm{P}=0.01$, among males this is $1.2 \%$ higher compared to females). Among females a highly significant $(\mathrm{P}<0.001)$ excess was registered in 6 , and among males in 5 out of the 10 examined body proportions (Table 1).

The joint variability of the examined metric characteristics of $P$. melanarius (Figs. 5-6) indicates that there are more complex regularities in the distribution of body proportions then was earlier described by Sharova (1981). Regression analysis showed significant differences for the slope of the curve (coefficient $a$ in the equation $y=a x+b$ ) among males and females. From this it can be seen that certain individuals can significantly diverge from the cluster of the main selection, which is more evident among females.

The coefficient of variation (ratio of average quadratic deviation to average quantity, expressed as a percentage) is minimal for proportions and is maximal for metric characteristics (Fig. 7), which indicates isometric differences between $P$. melanarius males and females. The most constant index in the studied selection was the ratio of average arithmetical mean of head width, prothorax and elytra to body length (males: $2.1 \%$, females: $2.3 \%$ ).

Out of the 10 analysed non-metric characteristics (shape of front edge of the labrum, number of setaebearing pores on the labrum, extent of indumentums on corners of the labrum, depth of setae-bearing pores on the labrum, shape of front edge of clypeus, disposition of mandible, depth of furrow on left and right mandibles, transverse groove on front edge of prothorax, and impression near front edge of prothorax) a statistically significant sexual dimorphism $(\mathrm{P}=0.01)$ was registered only for shape of front edge of the labrum. Among males front edge of the labrum is mostly slightly concave, among females highly concave (Table 1, Fig. 8).

Among most specimens the left mandible is disposed on top of the right ( $79 \%$ of males and $75 \%$ females), though about a quarter of individuals in the studied P. melanarius population have another disposition of the maxillae. The biological meaning of differences in mandible disposition remains uncertain, though we can presume that their proportions are significant for 

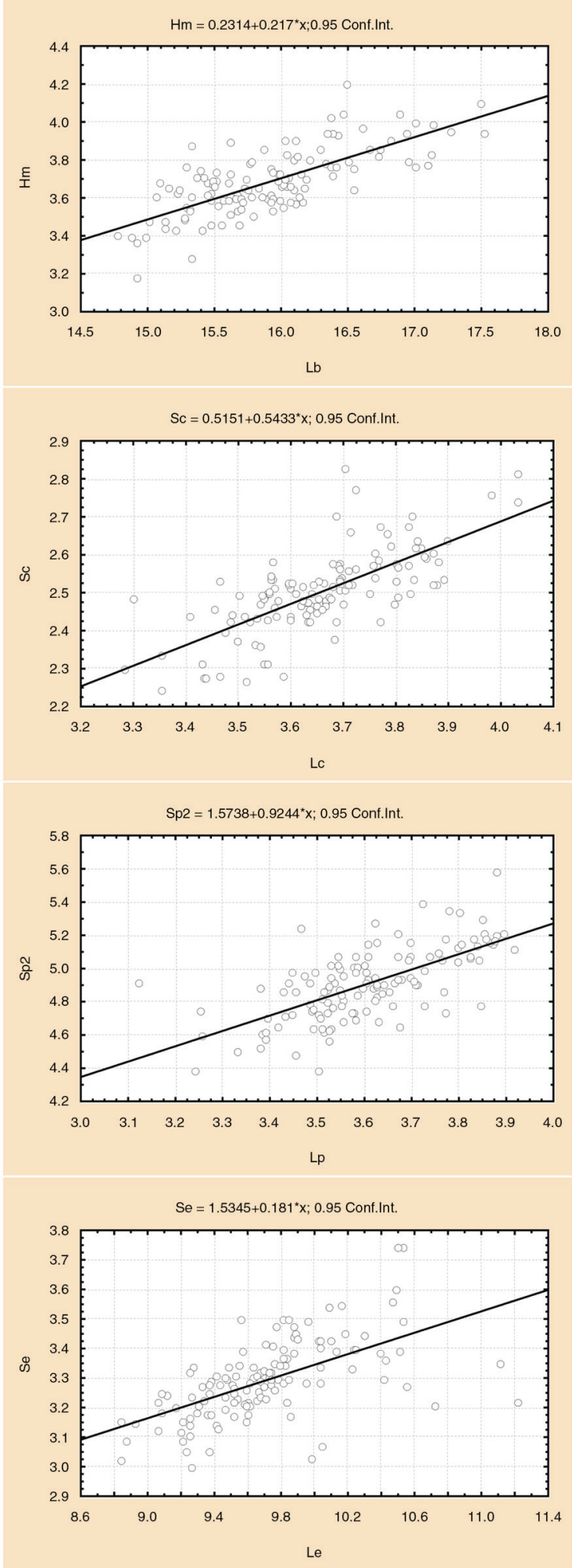

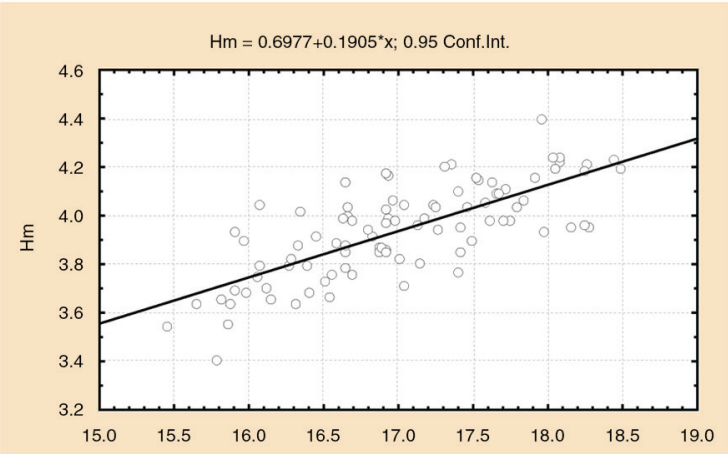

Lb

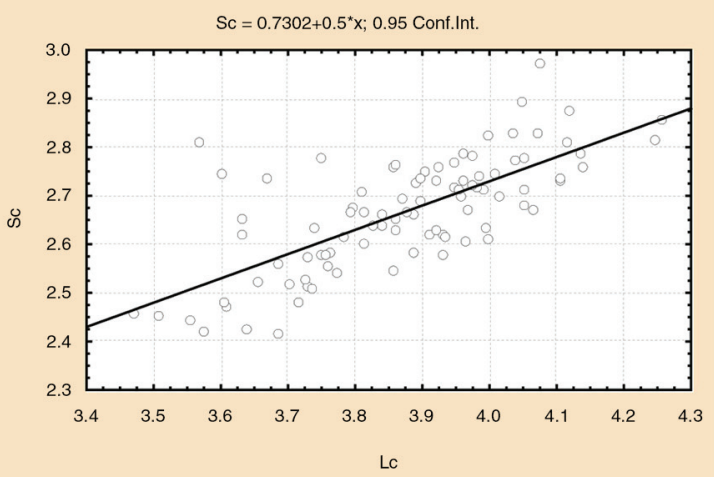

LC

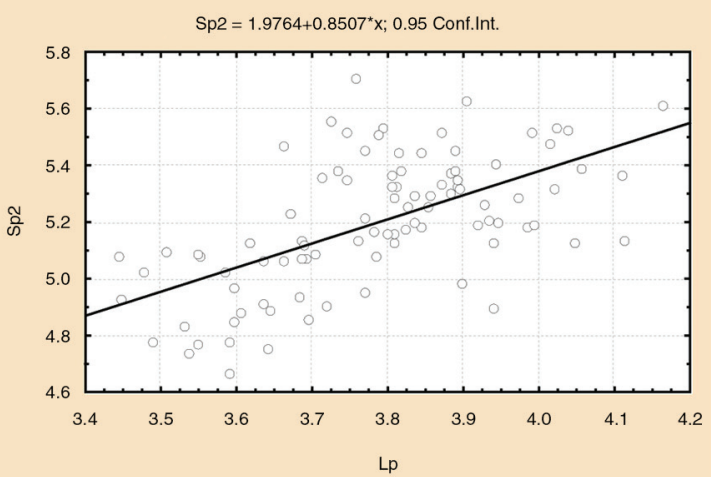

Lp

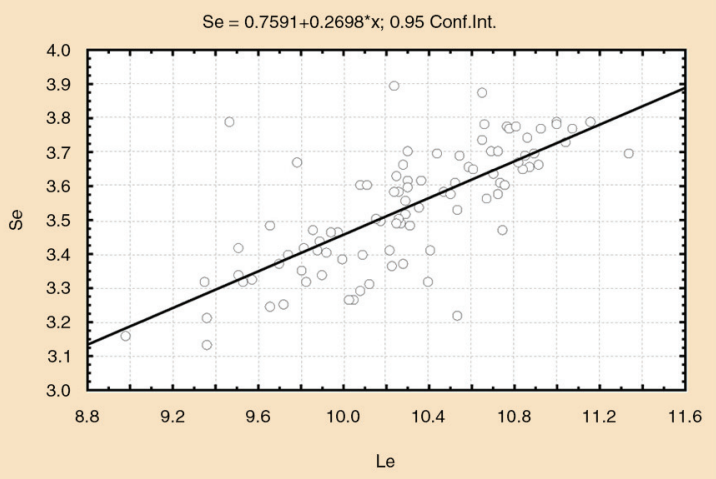

Fig. 5.- Regression analysis of linear body measurements of $P$. melanarius: for name of the characteristic see Notes to Table 1. On the left males $(n=130)$, on the right females $(n=95)$; abscissa and ordinate axes, value of the characteristic $(m m)$.

Fig. 5.- Regresión lineal de las medidas corporales de $P$. melanarius: para el nombre de los caracteres véanse las Notas de la Tabla 1. A la izquierda, machos $(n=130)$ y a la derecha, hembras $(n=95)$; abscisas y ordenadas, medidas $(m m)$.

eating gastropods, the cuttlebones of which also have different variants of spatial orientation. This question needs further research.
A combined analysis of metric and non-metric characteristics enables the general factors to be identified that define the morphological peculiarities of 

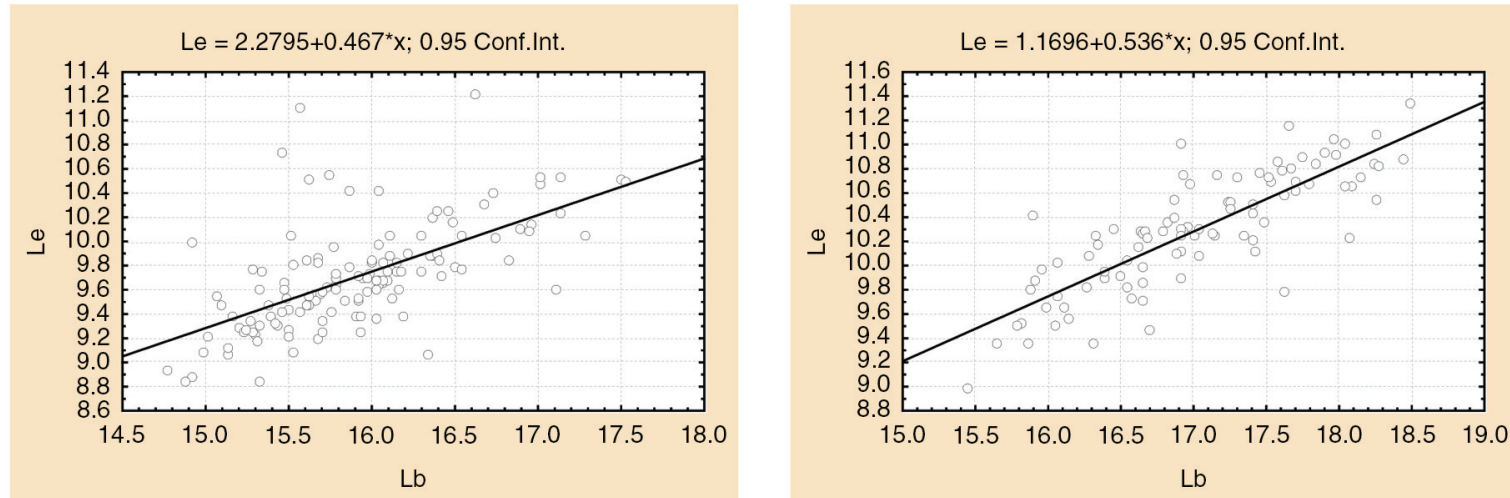

$\mathrm{Lb}$
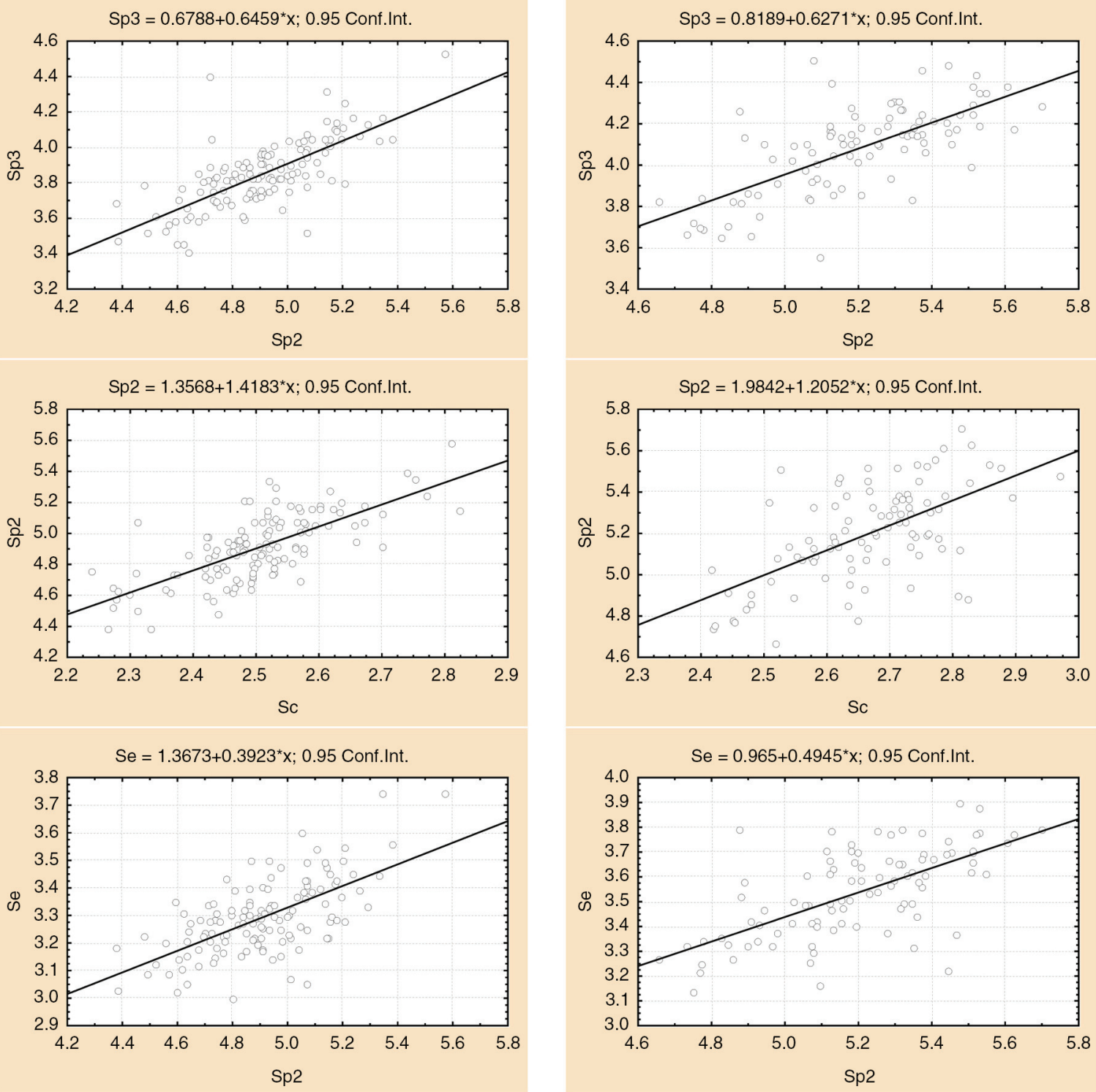

Fig. 6.- Regression analysis of linear body measurements of $P$. melanarius: for name of the characteristic see Notes to Table 1. On the left males $(n=130)$, on the right females $(n=95)$; abscissa and ordinate axes, value of the characteristic $(m m)$.

Fig. 6.- Regresión lineal de las medidas corporales de P. melanarius: para la denominación de los caracteres véanse las Notas de la Tabla 1. A la izquierda, machos $(n=130)$ y a la derecha, hembras $(n=95)$; abscisas y ordenadas, medidas $(m m)$.

P. melanarius individuals. Using PCA analysis (Figs. 9-10, Table 2) we found that $45.2 \%$ of the morphologic variability of the studied population is determined by factor 1 , which we identified as the sex of the P. melanarius specimens (in Fig. 10 in the positive zone of the factor are mostly males with 


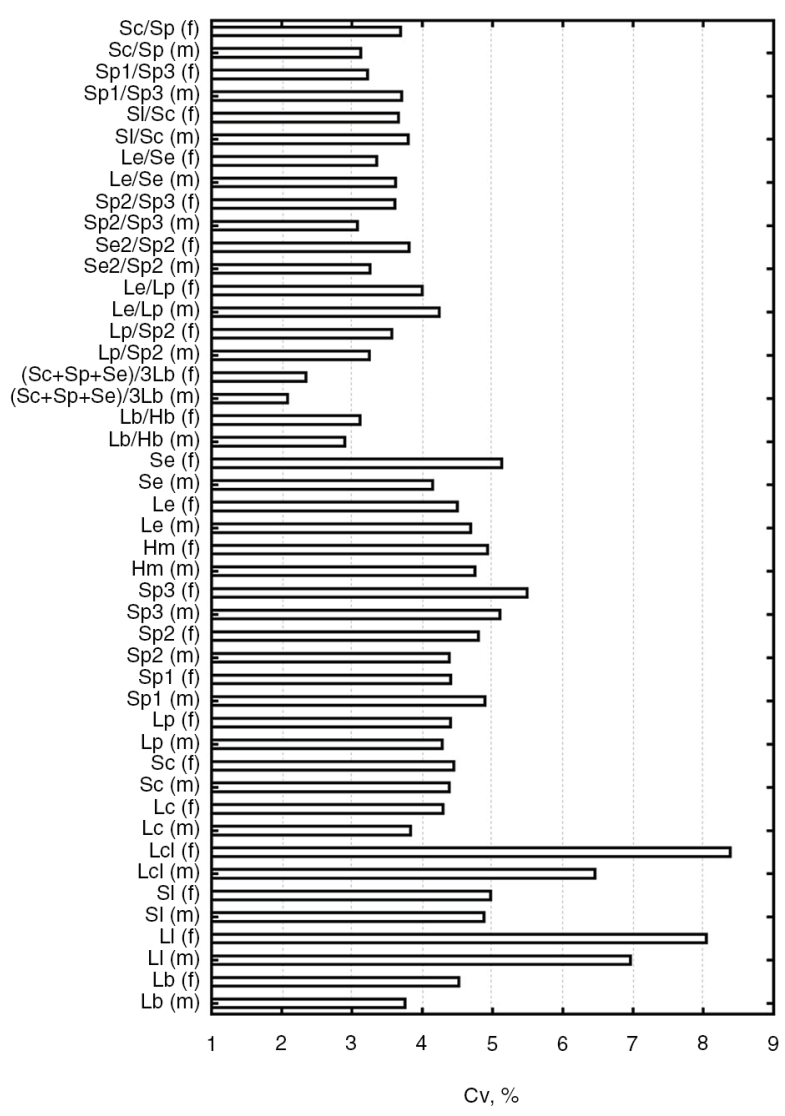

Fig. 7.- Values of coefficient of variation for 13 metric characteristics and 10 body proportions of $P$. melanarius males ( $m$ ) and females ( $f$ ), from a Ukrainian population (Zapadniy, Dnipropetrovsk, Ukraine): For the names of the characteristics and the indices see Notes to Table 1.

Fig. 7.- Coeficiente de variación para 13 caracteres métricos y 10 medidas corporales de $P$. melanarius machos $(m)$ y hembras (f) de una población ucraniana (Zapadniy, Dnipropetrovsk, Ucrania). Para la denominación de los caracteres y los índices véanse las Notas de la Tabla 1.

numbers from 1 to 130 , in the negative mostly females with numbers from 131 to 225). The whole complex of metric characteristics (length and width of head, prothorax, elytra and parts of the head, body height) together is determined by factor 1 , the individual's sex (Fig. 9). The consistency of variation of these characteristics is upheld also by low coefficients of variations in body proportions (indices) compared to linear measurements (Fig. 7).

The remaining 20 factors contributing to the morphologic variability of $P$. melanarius individuals (Table 2 ) ranged from $0.3 \%$ to $6.3 \%$ of the total dispersion (total: $54.8 \%$ ). The point of directional turning, where the derivative changes its sign from positive to negative, is situated between factors 10 and 11 (Table 2), thus only factors 1-10 have a practical effect upon the morphology of $P$. melanarius individuals.

Factor 2 (6.3\% of dispersion) differentiates nonmetric characteristics, not affecting the metric characteristics. It affects the shape of the clypeus and formation of impressions on the front edge of the

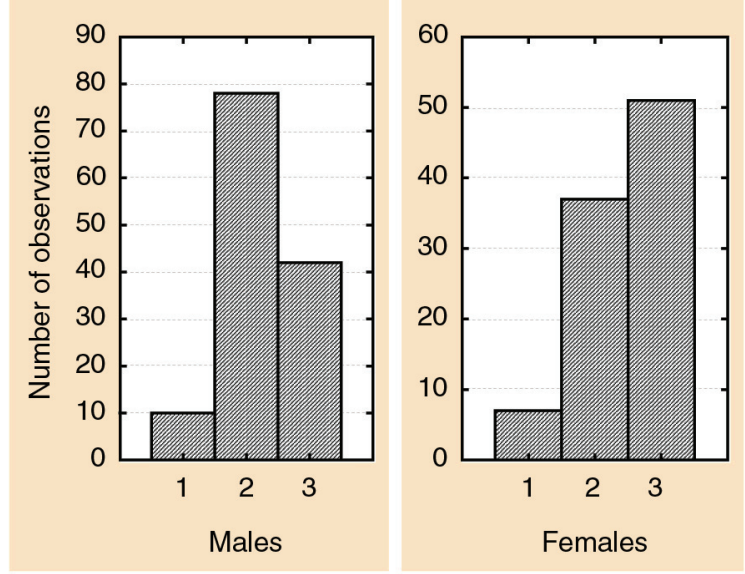

Fig. 8.- Form of front edge of labrum in $P$. melanarius males and females from a Ukrainian population (Zapadniy, Dnipropetrovsk, Ukraine). 1, straight; 2 , slightly concave; 3 , strongly concave.

Fig. 8.- Forma del borde anterior del labro en machos y hembras de $P$. melanarius de una población ucraniana (Zapadniy, Dnipropetrovsk, Ucrania). 1, recto; 2, ligeramente cóncavo; 3, muy cóncavo.

prothorax. Factor $3(6.0 \%$ of dispersion) manifests itself in the extent of indumentums at the corners of the labrum and depth of furrows in the mandibles. Factor $4(5.4 \%$ of dispersion) is identified by the formation of transverse grooves on the prothorax. Factor 5 (5.1\% of dispersion) influences the disposition of mandibles (right on top of left or left on top of the right), and is also connected with depth of furrows in the mandibles. Factor 6 (4.7\% of dispersion) influences the quantity of setae-bearing pores on the labrum and formation of impressions near the edge of the prothorax.

In this way the results of PCA analysis upheld the high consistency in variations in linear body sizes of $P$. melanarius individuals in the studied population, and also allowed us to numerically evaluate the significance of such non-metric characteristics as shape of clypeus, impressions on front edge of the prothorax, indumentation of front corners of the labrum, depth of furrows on mandibles, disposition of mandibles, number of setae-bearing pores on the labrum and impressions near the front edge of the prothorax.

In the course of our previous research we registered the individual differences in the food range of certain P. melanarius individuals (Korolev \& Brygadyrenko, 2014). In our current research we attempted to distinguish morphologically distinct groups of individuals according to a single (Figs. 2-4, 8), several (Figs. 5-6) or all examined characteristics (Figs. 9-10). However, no more or less distinguished morphological groups (morphotypes) were found in the population. Morphological homogeneity (normal distribution of individuals) of population was violated for a number of characteristics by the appearance of asymmetry or excess for certain features/parameters or ratios of metric functions. 
Table 2.- Significance of factors which define metrical and non-metric characteristics of the studied population of $P$. melanarius (Zapadniy, Dnipropetrovsk, Ukraine), obtained through PCA analysis

Tabla 2.- Importancia de los factores que definen las características métricas y no métricas de la población de $P$. melanarius estudiada (Zapadniy, Dnipropetrovsk, Ucrania), obtenidos mediante Análisis de Componentes Principales (PCA)

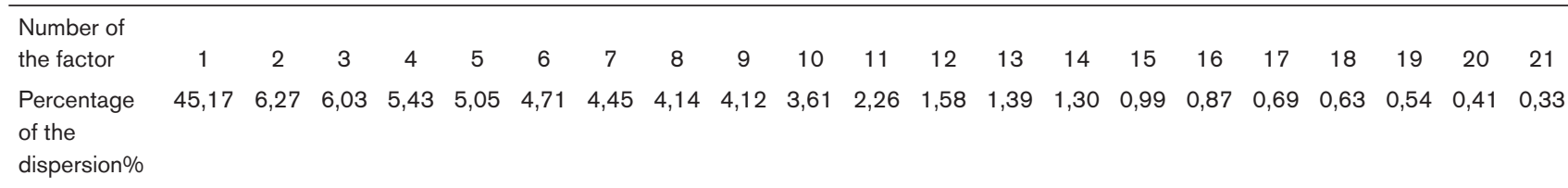

The use of certain invertebrate species (for example ground beetles with no large-scale migration capacity and which accumulate large amounts of toxins in the conditions of anthropogenic activity) is suitable for incorporation into regional programs of environmental monitoring (Lindqvist \& Block, 2001; Pakhomov \& Brygadyrenko, 2005).

\section{Conclusions}

For most metric characteristics (except the length of flight wings) $P$. melanarius shows a clear sexual dimorphism (females are larger than males by $6.56 \pm 0.96 \%$ ). The studied population, judging by the proportion of long-winged individuals (1.3\%), can be classified as a stable lowland population of P. melanarius. For evaluation of the most significant body proportions 10 indices were analysed that manifested much lower sexual differences $(0.26 \pm 0.86 \%)$ compared to linear measurements $(6.56 \pm 0.96 \%)$. Females and males are practically isomorphic: with decrease of one metric characteristic, another decrease proportionately. A statistically significant excess was registered for 6 body proportions for females; and 5 out of 10 evaluated proportions for males. Regression analysis of metric characteristics shows statistically significant differences of angle of slope of the curve for most metric characteristics of males and females. The most constant in the studied selection was index of ratio of arithmetical mean for width of head, prothorax and elytra to body length (males' CV: $2.1 \%$, females' CV: $2.3 \%$ ). Out of 10 non-metric characteristics statistically significant sexual dimorphism is registered only for shape of the front edge of the labrum. Males mostly have a slightly concave and females have a strongly concave upper edge of the labrum.

With the use of regression analysis it was found that $45.2 \%$ of morphological variability is conditioned by sex. The whole complex of metric characteristics (length and width of head, prothorax, elytra and parts of head, height of body) varies simultaneously among individuals of different sex. We did not succeed in finding more or less distinct morphological groups (morphotypes) in the studied P. melanarius population. A normal distribution of individuals in the population was violated for a number of characteristics by the appearance of a statistically significant asymmetry or excess of certain features or ratios of metric characteristics.
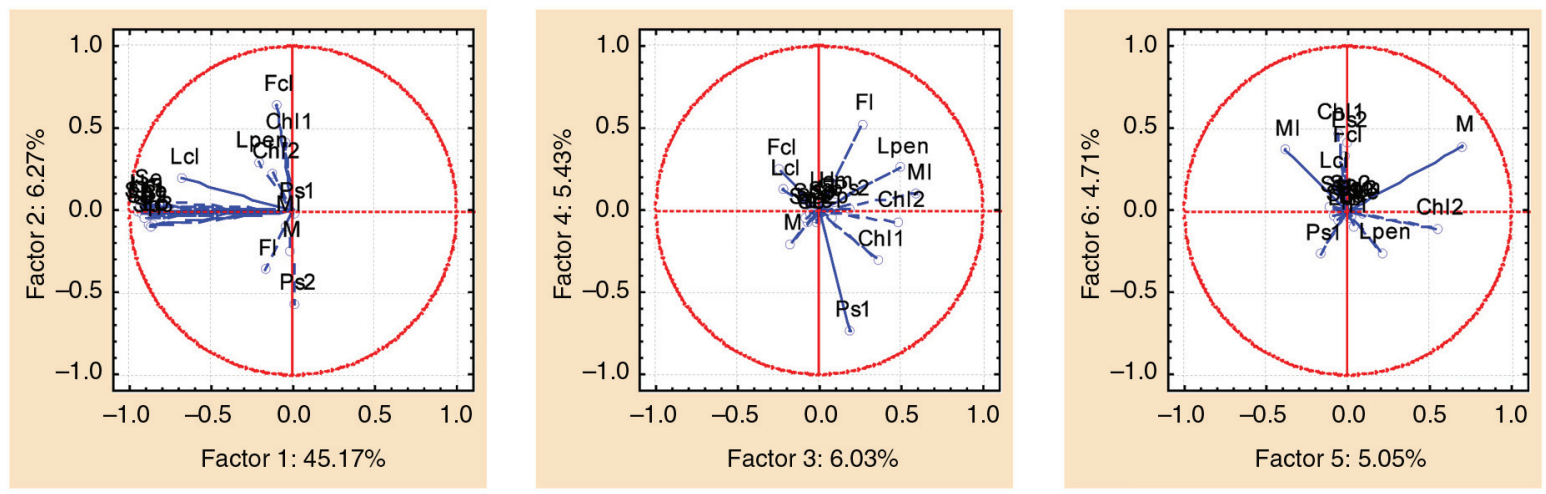

Fig. 9.- Graphic interpretation of results of PCA analysis of morphological variability of $P$. melanarius individuals from a Ukrainian population (Zapadniy, Dnipropetrovsk, Ukraine): for the names of the characteristics see Notes to Table 1.

Fig. 9.- Interpretación gráfica de los resultados del Análisis de Componentes Principales de la variabilidad morfológica de ejemplares de una población ucraniana (Zapadniy, Dnipropetrovsk, Ucrania) de P. melanarius. Para las abreviaturas véanse las Notas de la Tabla 1. 


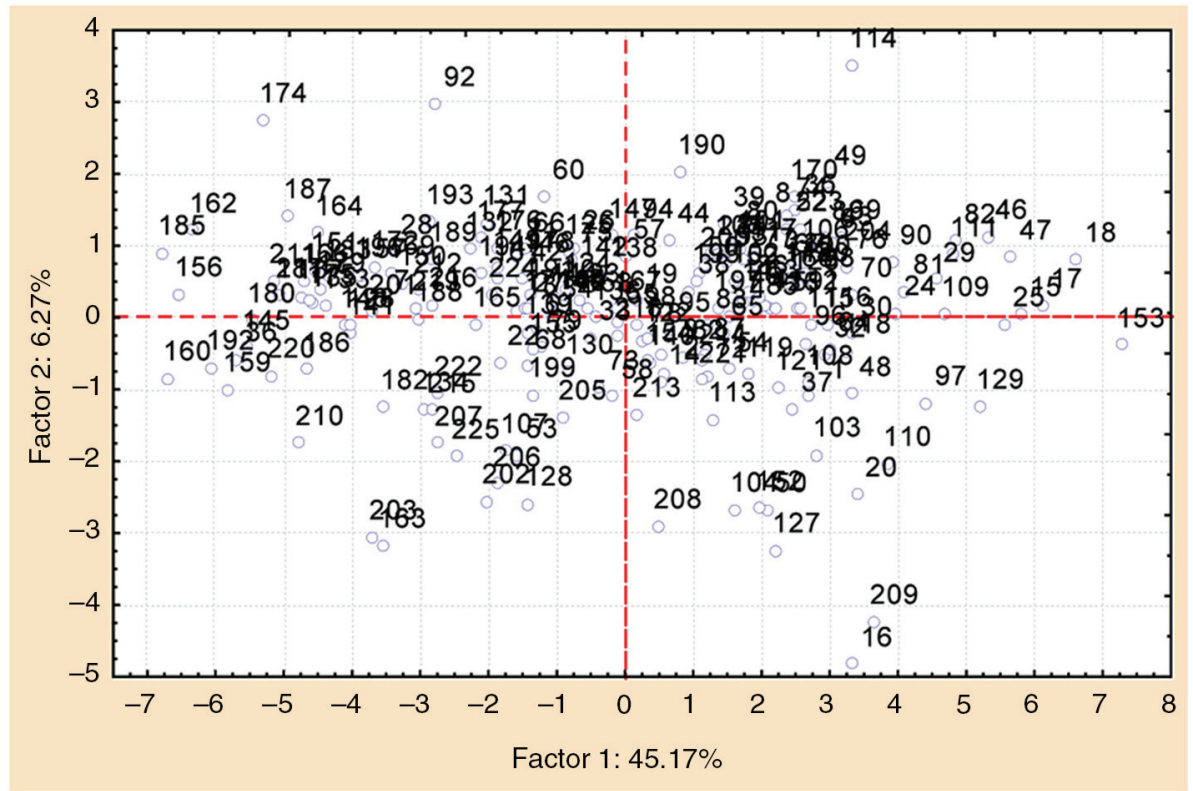

Fig. 10.- Diagram of dispersion of 225 P. melanarius specimens from a Ukrainian population (Zapadniy, Dnipropetrovsk, Ukraine) in the gradient of factors 1 and 2 . Specimens $1-130$, males; $131-225$, females.

Fig. 10.- Diagrama de dispersión de 225 ejemplares de $P$. melanarius procedentes de una población ucraniana (Zapadniy, Dnipropetrovsk, Ukraine) en el gradiente de los factores 1 y 2 . Ejemplares 1-130, machos; 131-225, hembras.

\section{References}

Basedov, T., 1994. Phenology and egg production in Agonum dorsale and Pterostichus melanarius (Col., Carabidae) in winter wheat fields of different growing intensity in Northern Germany. In: K. Desender, M. Dufrêne, M. Loreau, M. L. Luff \& J.-P. Maelfait (Eds.). Carabid Beetles: Ecology and Evolution. Kluwer, Series Entomologica, nr. 51. Dordrecht, Boston \& London: 101-108. http:// dx.doi.org/10.1007/978-94-017-0968-2_15

Brygadyrenko, V. V. \& Fedorchenko, D. O., 2008. Morfologichna minlyvist' populjacii' Carabus hungaricus scythus (Coleoptera, Carabidae) v umovah ostrova Hortycja (Zaporiz'ka oblast'). Visnik Dnipropetrovs'kogo Universitetu. Serîa Biologiâ, Ekologîa, 16(1): 20-27. http://dx.doi.org/10.15421/010804

Brygadyrenko, V. V. \& Korolev, O. V., 2006. Osoblyvosti spektra zhyvlennja Pterostichus melanarius (Coleoptera Carabidae) u laboratornyh umovah. Bulletin of Bilocerkivskiy State Agrarian University, 43: 67-71.

Brygadyrenko, V. V. \& Reshetniak, D. Y., 2014. Morphological variability among populations of Harpalus rufipes (Coleoptera, Carabidae): What is more important - the mean values or statistical peculiarities of distribution in the population? Folia Oecologica, 41(2): 109-133.

Brygadyrenko, V. V. \& Slynko, V.O., 2015. Morphological variability of Bembidion articulatum (Coleoptera, Carabidae) populations: Linear dimensions depend on sex, while morphological indices depend on ecosystems. International Journal of Applied Environmental Sciences, 10(1): 163-187.

Chapman, P. A., Armstrong, G. \& McKinlay, R. G., 1999. Daily movements of Pterostichus melanarius between areas of contrasting vegetation density within crops. Entomologia Experimentalis et Applicata, 91: 477-480. http://dx.doi.org/10.1046/j.1570-7458.1999.00516.x

Collins, K. L., Boatman, N. D., Wilcox, A., Holland, J. M. \& Chaney, K., 2002. Influence of beetle banks on cereal aphid predation in winter wheat. Agriculture, Ecosystems \& Environment, 93(1-3): 337-350. http://dx.doi. org/10.1016/S0167-8809(01)00340-1

Currie, C. R. \& Digweed, S. C., 1996. Effect of substrate depth on predation of larval Pterostichus adstristus Eschscholtz by adults of $P$. melanarius (Illiger) (Coleoptera: Carabidae). The Coleopterists Bulletin, 50(3): 291-296.

Daly, H. V., Doyen, J. T. \& Purcell, A. H., 1998. Introduction to insect biology and diversity. $2^{\text {nd }}$ edition. Oxford University Press. Oxford. 696 pp.

Den Boer, P. J., 1985. Fluctuations on density and survival of carabid populations. Oecologia (Berlin), 67: 322-330. http://dx.doi.org/10.1007/BF00384936

Desender, K., van den Broeck, D. \& Maelfait, J.-P., 1985. Population biology and reproduction in Pterostichus melanarius Ill. (Coleoptera, Carabidae) from a heavily grazed pasture ecosystem. Mededelingen van de Faculteit Landbouwwetenschappen van de Rijksuniversiteit Gent, 50: 567-575.

Fadl, A., Purvis, G. \& Towey, K., 1996. The effect of time of soil cultivation on the incidence of Pterostichus melanarius (Illig.) (Coleoptera: Carabidae) in arable land in Ireland. Annales Zoologici Fennici, 33: 207-214.

Fournier, E. \& Loreau, M., 2002. Foraging activity of the carabid beetle Pterostichus melanarius Ill. in field margin habitats. Agriculture, Ecosystems \& Environment, 89(3): 253-259. http://dx.doi.org/10.1016/S0167-8809 (01)00216-X 
Frampton, G. K., Cilgi, T., Fry, G. L. A. \& Wratten, S. D., 1995. Effects of grassy banks on the dispersal of some carabid beetles (Coleoptera: Carabidae) on farmland. Biological Conservation, 71(3): 347-355. http://dx.doi. org/10.1016/0006-3207(94)00072-X

Geodakyan, V. A., 1983. Jevoljucionnaja logika differenciacii polov. Priroda, 1: 70-80.

Hurka, K., 1975. Laboratory studies on the life cycle of Pterostichus melanarius (Ill.) (Coleoptera, Carabidae). Věstnik Československé společnosti zoologické, 39(4): 265-274.

Hurka, K., 1996. Carabidae of the Czech and Slovak Republics. Kabourek. Zlin. 565 pp.

Irmler, U., 2003. The spatial and temporal pattern of carabid beetles on arable fields in Northern Germany (SchleswigHolstein) and their value as ecological indicators. Agriculture, Ecosystems \& Environment, 98(1-3): 141-151. http://dx.doi.org/10.1016/S0167-8809(03)00076-8

Jørum, P., 1980. Life cycles and annual activity patterns of Pterostichus melanarius (Illig.) and P. niger (Schall.) (Coleoptera: Carabidae) in a Danish beech wood. Entomologiske Meddelelser, 48(1): 19-25.

Kitaev, K. A., Udalov, M. B. \& Benkovskaya, G. V., 2011. Molecular-genetic analysis of predation among insects in agrocenoses. Ecological Genetics, 9(4): 15-24.

Korolev, O. V. \& Brygadyrenko, V. V., 2012a. Porivnjal'nyj analiz trofichnyh perevag Pterostichus melanarius (Coleoptera, Carabidae) za riznyh umov laboratornogo utrymannja. Ekosistemy, ikh Optimizatziya i Okhrana, 6: $178-190$

Korolev, O. V. \& Brygadyrenko, V. V., 2012b. Trofichni zv'jazky Pterostichus melanarius (Coleoptera, Carabidae) iz dominantnymy vydamy bezhrebetnyh lisovyh ekosystem Stepovogo Prydniprov'ja. Visnik Dnipropetrovs 'kogo Universitetu. Serîa Biologiâ, Ekologîa, 20(1): 48-54. http://dx.doi.org/10.15421/011207

Korolev, O. V. \& Brygadyrenko, V. V., 2014. Influence of individual variation in the trophic spectra of Pterostichus melanarius (Coleoptera, Carabidae) on the adaptation possibilities of its population. Folia Oecologica, 41: 34-43.

Kryzhanovskij, O. L., Belousov, I. A., Kabak, I. I., Kataev, B. M., Makarov, K. V. \& Shilenkov, V. G., 1995. A checklist of the ground-beetles of Russia and adjacent lands (Insecta, Coleoptera, Carabidae). Pensoft. Sofia \& Moscow. 271 pp.

Lindqvist, L. \& Block, M., 2001. Metal pollution and fat accumulation in the carabid beetle Pterostichus melanarius (Coleoptera, Carabidae). Bulletin of Environmental Contamination and Toxicology, 66(2): 184-188. http://dx.doi.org/10.1007/s001280000223

Lovei, G. L., 1996. Ecology and behavior of ground beetles (Coleoptera: Carabidae). Annual Review of Entomology, 41: 231-256. http://dx.doi.org/10.1146/annurev. en.41.010196.001311

Matalin, A. V., 2003. Variations in flight ability with sex and age in ground beetles (Coleoptera, Carabidae) of South-Western Moldova. Pedobiologia, 47(4): 311-319. http://dx.doi.org/10.1078/0031-4056-00195
Matalin, A. V., 2006. Geograficheskaja izmenchivost' zhiznennogo cikla Pterostichus melanarius (Coleoptera, Carabidae). Zoologicheskii Zhurnal, 85(5): 573-585.

Matalin, A. V., 2007. Tipologija zhiznennyh ciklov zhuzhelic (Coleoptera, Carabidae) Zapadnoj Palearktiki. Zoologicheskii Zhurnal, 86(10): 1196-1210.

Pakhomov, O. Y. \& Brygadyrenko, V. V., 2005. Koncepcija systemy zahodiv z ohorony navkolyshn'ogo pryrodnogo seredovyshha Dnipropetrovs'koi' oblasti na 2005-2015 roky. Visnik Dnipropetrovs'kogo Universitetu. Seriâ Biologiâ, Ekologîa, 13(1): 211-224. http://dx.doi.org/ $10.15421 / 010538$

Pollet, M. \& Desender, K., 1985. Adult and larval feeding ecology in Pterostichus melanarius Ill. (Coleoptera, Carabidae). Mededelingen van de Faculteit Landbouwwetenschappen van de Rijksuniversiteit Gent, 50(2b): 581-594.

Raworth, D. A. \& Choi, M.-Y., 2001. Determining numbers of active carabid beetles per unit area from pitfalltrap data. Entomologia Experimentalis et Applicata, 98: 95-108. http://dx.doi.org/10.1023/A:1018776204443

Raworth, D. A., Robertson, M. C. \& Bittman, S., 2004. Effects of dairy slurry application on carabid beetles in tall fescue, British Columbia, Canada. Agriculture Ecosystems \& Environment, 103(3): 527-534. http://dx.doi. org/10.1016/j.agee.2003.11.004

Sharova, I. C., 1981. Zhiznennye formy zhuzhelic (Coleoptera, Carabidae). Nauka. Moscow.

Sota, T., Takami, Y., Kubota, K., Ujiie, M. \& Ishikawa, R., 2000. Intraspecific body size differentiation in species assemblages of the carabid subgenus Ohomopterus in Japan. Population Ecology, 42: 279-291.

Symondson, W. O. C., 1997. Does Tandonia budapestensis (Mollusca: Pulmonata) contain toxins? Evidence from feeding trials with the slug predator Pterostichus melanarius (Coleoptera, Carabidae). Journal of Molluscan Studies, 63: 575-579.

Thiele, H. U., 1977. Carabid beetles in their environments. Springer. Berlin. XVII+372 pp.

Thomas, C. F. G., Parkinson, L. \& Marshall, E. J. P., 1998. Isolating the components of activity-density for the carabid beetle Pterostichus melanarius in farmland. Oecologia, 116(1-2): 103-112. http://dx.doi.org/10.1007/ s004420050568

Thomas, R. S., Glena, D. M. \& Symondson, W. O. C., 2008. Prey detection through olfaction by the soil-dwelling larvae of the carabid predator Pterostichus melanarius. Soil Biology and Biochemistry, 40(1): 207-216. http:// dx.doi.org/10.1016/j.soilbio.2007.08.002

Wallin, H., 1988. The effects of spatial distribution on the development and reproduction of Pterostichus cupreus L., P. melanarius Illiger, P. niger Schaller and Harpalus rufipes De Geer (Coleoptera, Carabidae) on arable land. Journal of Applied Entomology, 106: 483-487. http://dx.doi.org/10.1111/j.1439-0418.1988.tb00622.x

Wallin, H. \& Ekbom, B., 1994. Influence of hunger level and prey densities on movement patterns in three species of Pterostichus beetles (Coleoptera: Carabidae). Environmental Entomology, 23(5): 1171-1181. http:// dx.doi.org/10.1093/ee/23.5.1171 